\title{
GAMBARAN PERILAKU PERSONAL HYGIENE MENSTRUASI REMAJA PUTRI YANG MENGIKUTI PELATIHAN DAN PEMBINAAN PKPR DI SMP PGRI 13 WILAYAH KERJA PUSKESMAS SINDANG BARANG KOTA BOGOR TAHUN 2017
}

\author{
Jeanita Hanissa ${ }^{1}$, Andreanda Nasution ${ }^{2}$, Asri Masitha Arsyati ${ }^{3}$
}

\footnotetext{
${ }^{1}$ Konsentrasi Promosi Kesehatan, Program Studi Kesehatan Masyarakat Fakultas Ilmu Kesehatan, Universitas Ibn Khaldun Bogor. Email : jejejeanhsd@gmail.com

${ }^{2}$ Konsentrasi Promosi Kesehatan, Program Studi Kesehatan Masyarakat Fakultas Ilmu Kesehatan, Universitas Ibn Khaldun Bogor. Email : andre.anda8861@gmail.com

${ }^{3}$ Konsentrasi Promosi Kesehatan, Program Studi Kesehatan Masyarakat Fakultas Ilmu Kesehatan, Universitas Ibn Khaldun Bogor. Email : asri.masitha@gmail.com
}

\begin{abstract}
Abstrak
Praktek dalam menjaga kebersihan diri (personal hygiene) saat menstruasi adalah perilaku penting dalam kesehatan khususnya pada remaja putri. Dampak dari tidak menjaga kebersihan diri saat menstruasi adalah infeksi jamur dan bakteri. Pelayanan Kesehatan Peduli Remaja (PKPR) adalah program yang dirancang Kementerian Kesehatan RI untuk mengedukasi dan menekan jumlah kejadian atau resiko penyakit terhadap remaja salah satunya adalah praktek dalam menjaga kebersihan pada organ. Tujuan penelitian ini untuk mengetahui informasi yang mendalam tentang gambaran perilaku personal hygiene menstruasi remaja putri di sekolah SMP PGRI 13 Kota Bogor Tahun 2017. Desain penelitian kualitatif ini adalah Rapid Assesment Procedure (RAP) dan menggunakan metode wawancara mendalam (indepth interview) dalam pengumpulan data. Hasil penelitian ini menunjukkan perbedaan perilaku yang signifikan antara siswi yang mengikuti PKPR dan tidak mengikuti PKPR. Kesimpulan yang didapat bahwa perilaku personal hygiene remaja di SMP PGRI 13 Kota Bogor tidak dipengaruhi oleh pelatihan dan pembinaan PKPR, melainkan sebagian besar remaja dipengaruhi oleh dukungan sosial.
\end{abstract}

Kata Kunci : personal hygiene, menstruasi, remaja

\section{Pendahuluan}

Carsinoma Cervics Uteri atau kanker serviks ini adalah Human Papilloma Virus (HPV) yang disebut sebagai penyakit pembunuh wanita nomor 1 di Indonesia pada tahun 2004 sebesar $45 \%$ yang diakibatkan oleh bakteri dan jamur (Yusiana, 2015). Pada tahun 2013 tertinggi di Indonesia, dengan estimasi jumlah penderita kanker serviks terbanyak di Jawa Tengah sebanyak 19.734 kasus dan Jawa Timur sebanyak 21.313 kasus (Infodatin, Pusat Data dan Informasi Kanker Kemenkes, 2015).

Gejala dari kanker serviks biasanya terjadi keputihan yang lama dan tidak diobati, selain itu juga terjadi karena bahan-bahan kimia yang salah satunya adalah bahan pemutih yang ada pada pembalut yang tidak berkualitas yang merupakan produk daur ulang (Rahmayanti, 2012). Menurut Departemen Kesehatan Provinsi Jawa Barat tahun 2012 
sekitar 316 orang mengalami infeksi pada genitalia eksternal, dan 592 orang mengalami keputihan pada remaja putri (Profil Kesehatan Provinsi Jawa Barat, 2012). Kurangnya keterampilan menjaga kebersihan saat menstruasi mengakibatkan sebesar $88,1 \%$ remaja putri pernah mengalami keputihan dengan frekuensi kejadian 15,3\% "kadang-kadang", 61\% "sering" dan 3,4\% "selalu" (Fitriyah, 2014). Pada penelitian Izzati dan Reni (2014) dengan Khasanah et al (2015) terdapat $42,9 \%$ remaja putri berpengetahuan kurang, $7,4 \%$ dan $2,71 \%$ diantaranya memiliki pelaksanaan buruk tentang personal hygiene saat menstruasi.

Penelitian United Nation Children Fund (UNICEF) di Indonesia pada 2015 menemukan fakta 1 dari 6 anak perempuan terpaksa tidak masuk sekolah selama satu hari atau lebih, pada saat menstruasi. Remaja di perkotaan mendapat sumber informasi mengenai kebersihan menstruasi dari Ibu sebanyak $60 \%$ dan di desa 58\%, dengan memberikan informasi mengenai waktu menarche (Usia pertama kali menstruasi), cara membersihkan pembalut dan mengatasi gejala seperti rasa sakit atau bau (UNICEF Indonesia, 2015). Menurut Survei Demografi dan Kesehatan Indonesia (SDKI) sebagian besar remaja putri membicarakan kesehatan reproduksi dengan teman $60 \%$, ibu $44 \%$, dan guru
43\% (SDKI, 2012). Diketahui bahwa ada pengaruh teman sebaya sebanyak 2,963 kali lebih besar mendukung perilaku kebersihan pada saat menstruasi (Suryati, 2012).

Peranan Puskesmas dalam program Pelayanan Kesehatan Peduli Remaja (PKPR) adalah sebagai ujung tombak pemberi pelayanan kesehatan di masyarakat termasuk remaja. Menurut Arsani et al (2012) di Bali program PKPR yang dicanangkan Puskesmas Buleleng 1 sebagian besar sudah terlaksana dengan baik, namun masih terdapat 1 sasaran yang belum tercapai yaitu pembentukan konselor sebaya serta belum maksimalnya sosialisasi kepada remaja secara luas.

\section{Metode}

Penelitian ini merupakan penelitian study kualitatif Rapid Assessment Prosedure adalah jenis penelitian yang dilakukan dalam kurun waktu singkat yang dikenalkan oleh Schrimshaw SCM \& Hurtado (1992) untuk memperoleh informasi yang mendalam (Chandra, 2012).Penelitian ini akan dilaksanakan pada bulan Juni - Juli 2017, dengan menggunakan metode deskriptif kualitatif, dengan cara wawancara. Informan dipilih secara purposive sampling. Populasi pada penelitian ini adalah seluruh siswi di SMP PGRI 13 Kota Bogor.

Tabel. 1.1 Jumlah sampel informan berdasarkan karakteristik metode dan lokasi penelitian

\begin{tabular}{|c|c|c|c|c|c|}
\hline No. & $\begin{array}{l}\text { Karakteristik } \\
\text { Informan }\end{array}$ & $\begin{array}{l}\text { Siswi yang mengikuti } \\
\text { pelatihan dan } \\
\text { pembinaan PKPR }\end{array}$ & $\begin{array}{l}\text { Siswi yang tidak } \\
\text { mengikuti pelatihan dan } \\
\text { pembinaan PKPR }\end{array}$ & $\begin{array}{l}\text { Jumlah } \\
\text { sampel }\end{array}$ & Lokasi \\
\hline 1. & $\begin{array}{l}\text { Usia } \\
>12 \text { th } \\
<15 \text { th } \\
\text { Kelas }\end{array}$ & $\begin{array}{l}3 \\
3\end{array}$ & $\begin{array}{l}3 \\
3\end{array}$ & 12 & Sekolah \\
\hline \multirow[t]{2}{*}{2.} & $\begin{array}{l}\text { kelas VII } \\
\text { kelas VIII }\end{array}$ & $\begin{array}{l}3 \\
3\end{array}$ & $\begin{array}{l}3 \\
3\end{array}$ & 12 & Sekolah \\
\hline & & Jumlah & & 24 & \\
\hline
\end{tabular}


Total sampel dalam penelitian ini adalah 29 orang terdiri dari 24 informan siswa dan 5 informan kunci. Informan kunci terdiri dari Pembina kesiswaan, kepala sekolah, petugas puskesmas dan staff bagian PKPR Dinas Kesehatan Kota Bogor serta kepala bidang. Uraian karakteristik sampel, metode dan lokasi penelitian tercantum pada tabel 1.1 dan 1.2

Tabel 1.2. Jumlah Sample informan kunci berdasarkan karakteristik, metode dan lokasi penelitian

\begin{tabular}{|c|c|c|c|c|}
\hline No. & Informan & Metode & Jumlah & Lokasi \\
\hline 1. & Pembina Kesiswaan & $\begin{array}{l}\text { Wawancara } \\
\text { mendalam }\end{array}$ & 1 & Sekolah \\
\hline 2. & Kepala sekolah & $\begin{array}{l}\text { Wawancara } \\
\text { mendalam }\end{array}$ & 1 & Sekolah \\
\hline 3. & Petugas Puskesmas & $\begin{array}{l}\text { Wawancara } \\
\text { mendalam }\end{array}$ & 1 & Puskesmas \\
\hline 4. & $\begin{array}{l}\text { Staff Bagian PKPR Petugas } \\
\text { Dinas Kesehatan Kota Bogor }\end{array}$ & $\begin{array}{l}\text { Wawancara } \\
\text { mendalam }\end{array}$ & 1 & $\begin{array}{c}\text { Dinas Kesehatan Kota } \\
\text { Bogor }\end{array}$ \\
\hline 5. & $\begin{array}{l}\text { Kepala Bidang PKPR Petugas } \\
\text { Dinas Kesehatan Kota Bogor }\end{array}$ & $\begin{array}{l}\text { Wawancara } \\
\text { mendalam }\end{array}$ & 1 & $\begin{array}{c}\text { Dinas Kesehatan Kota } \\
\text { Bogor }\end{array}$ \\
\hline & Jumlah & & 5 & \\
\hline
\end{tabular}

\section{Hasil}

\section{1) Karakteristik}

Dari hasil karakteristik rata-rata usia informan adalah 14 tahun, dengan usia termuda adalah 12 tahun dan yang tertinggi usia 15 tahun. Pada kelas VII terdapat 4 orang yang tidak pernah mengikuti pelatihan dan pembinaan PKPR, sedangkan di kelas VIII ada 6 orang yang tidak mengikuti pelatihan dan pembinaan PKPR. Dengan rata-rata keadaan informan merupakan anak ke 3, hanya ada 1 informan adalah anak Tunggal dan 1 informan merupakan anak ke 4.

Sebagian besar informan tinggal dengan Orang Tua nya, namun terdapat 1 informan tinggal dengan Ayah, dan 1 informan tinggal dengan Kakak. Dengan rata-rata usia menarche informan pada usia 12 tahun, hanya ada 1 informan yang menstruasi di usia 10 tahun, dan 1 informan usia 14 tahun.

\section{2) Otonomi Pribadi}

Sedangkan dalam hasil penelitian kelompok yang mengikuti PKPR dan tidak mengikuti PKPR sebagian besar menjawab bahwa menstruasi itu tanda Akil Baligh atau pubertas bagi remaja putri, dengan gejala hampir semua mengalami "Sakit Perut" atau yang biasa mereka bilang "Sumbilangeun", badan lemas, dan berjerawat. Terdapat hasil yang sama pada kelompok yang mengikuti PKPR dan yang tidak mengikuti PKPR seluruh informan sudah melakukan keberishan diri selama menstruasi. 
"kalo dari sekolah itu menstruasi itu (tarik napas) ciri-ciri orang yang pubertas, terutama .. perempuan,

.." (Informan IN-22)

"Ganti rutin, terus jarang minum es sih akunya mah, kalo aku pribadi mah mandi, ngebersihin nya teh ngebuangnya juga harus pake plastik" (Informan IN-13)

"Suka jerawatan, suka lemes gitu... Setiap haid, di awal, terus suka minum obat, Pereda rasa nyeri......" (Informan IN-08)

\section{3) Situasi Aksi}

Berdasarkan hasil wawancara mendalam pada waktu mencuci organ kewanitaan kedua kelompok ini menjawab ketika mandi dan mengganti pembalut, namun terdapat 1 orang pada kelompok yang mengikuti PKPR menggunakan sabun jenis Krim untuk mencuci organ kewanitaan.

"sabun colek yang merek ekonomi tea.. Tau sendiri aja adanya itu kan bersih" (Informan IN-18)

Rata-rata mengganti pembalut dengan rentang waktu 3-4 jam, tetapi terdapat 3 informan yang mengganti 8 jam dalam sehari. Dengan rata-rata ketersediaan pembalut di rumah sebagian besar dibeli oleh Ibu, dan perilaku mencuci pembalut menggunakan sabun hingga dibuang. Mengganti celana dalam sehari selama menstruasi seluruh informan mengganti 2 kali dalam sehari selama menstruasi.

"Enak aja bersih, kadang kan suka gatel kalo pake sabun enak, dikasih tau sama mamah, beli di warung.... paling 2 kali kalo lagi bocor 4x.." (Informan IN-15)

"hemm berapa yah.. kalo dari pagi ampe sore ada lah 3, terus sore ke pagi 2" (Informan IN22)

\section{4) Tingkat Keparahan}

Temuan hasil wawancara tentang Keluhan yang dirasakan informan pada penelitian ini meliputi gatal-gatal dan sakit pada perut, intensitas keparahan yang di rasakan informan dalam kelompok yang mengikuti PKPR sebanyak 14 orang, 12 diantaranya mengalami gatal-gatal dan sakit pada perut di awal menstruasi. Lalu cara mengatasi keparahan yang di rasakan untuk gatal-gatal sebagian besar informan dengan mencuci organ kewanitaan dengan sabun, mengganti pembalut sesering mungkin, dan membasuh dengan air hangat. Sedangkan untuk mengatasi nyeri pada perut terdapat 6 informan mengkonsumsi obat, 5 diantaranya dengan mengkonsumsi jamu pereda rasa nyeri.

"Suka jerawatan, suka lemes gitu... Setiap haid, di awal, terus suka minum obat, Pereda rasa nyeri proris" (Informan IN-08)

"Ya palingan didiemin aja hehe nanti juga suka ilang sendiri sih..” (Informan IN-04)

"Biasanya obat maag gitu.. sama jamu kunyit asem yang di gendong” (Informan IN-14)

\section{5) Sumber Terhadap Informasi}

Berdasarkan hasil temuan di SMP PGRI 13 KOTA BOGOR dari hasil wawancara terdapat Informasi yang di dapat oleh kelompok informan yang mengikuti PKPR dan yang tidak mengikuti PKPR seluruhnya menjawab seputar kebersihan pembalut, merek pembalut dan informasi tentang menstruasi, dan hampir sebesar $80 \%$ didapat di Rumah.

\footnotetext{
"Lebih sering di rumah sama mamah dikasih tau” (Informan IN-01)

“...jangan minum air es, jangan minum eh kalo misal mau cepet minum sprit, jangan makan pedes-pedes, jangan makan buah nanas, udah itu aja sih... Suka diinternet suka dikasih sama ibu juga” (Informan IN-03)
} 
"aku punya info katanya temen dia langsung pingsan setelah keramas lagi haid, pas diperiksa sama dokter katanya pori-pori nya lagi terbuka, katanya.. tapi kalo aku kna belum pernah keramas kalau lagi haid jadi belom alami.. gitu" (Informan IN-22)

\section{6) Dukungan Sosial}

Seluruh informan menjawab kegiatan PKPR adalah Penyuluhan, dengan rata-rata mendapatkan informasi seputar Rokok, Narkoba, Lingkungan, DBD (Deman Berdarah Dengue) dan sebanyak 7 informan dalam kelompok yang mengikuti PKPR mendapatkan informasi seputar Reproduksi (menstruasi, kehamilan dini, dan HIVAIDS). Hampir seluruh informan dalam kedua kelompok ini menjawab Petugas dari Puskesmas dan dokter yang terlibat dalam pengisian pembinaan dan pelatihan PKPR.

Selain itu mitos yang didengar seluruh informan baik yang mengikuti PKPR atau yang tidak mengikuti PKPR hampir semua menjawab tidak boleh keramas dan menggunting kuku saat menstruasi, dan jangan keluar malam lewat kuburan. Sedangkan dalam pengertian PKPR dari 14 informan dalam kelompok yang mengkuti PKPR 12 diantaranya tidak mengetahui PKPR, hal ini tidak jauh berbeda dengan kelompok yang tidak mengikuti PKPR.

"kalo merek pembalut mah aku tau dari kakak..kan awalnya liat kakak dulu tuh pake apa, sebelumnya mah aku pake kain pembalutnya pas pertama-tama tuh, eh seterusnya dikasih tau sama kakak jangan pake itu pake pembalut" (Informan IN-08)

"pernah 1 kali aja, tentang DBD" (Informan IN-16)

\section{Pembahasan}

\section{1) Karakteristik}

Pada penelitian Hennegan et al (2016) yang mengatakan sebesar $86,9 \%$ remaja putri di Uganda mengalami menarche (usia menstruasi pertama) saat usia 12 tahun. Hal yang sama didapat di Indonesia berdasarkan hasil penelitian Tarigan (2013) mengatakan bahwa usia menarche remaja putri di SMPN 141 Jakarta 12 tahun, dan Yusiana (2015) mengatakan bahwa rata-rata usia remaja manarche 10-12 tahun.

Analisis mengenai karakteristik informan yang meliputi usia, usia menarche, kelas, sebagian besar informan mengalami menstruasi ketika 12 tahun, dan sebagian besar informan tinggal bersama orang tua. Karakteristik lainnya karena informan sebagian besar dari wilayah perbatasan antara Bogor Kota dengan Kabupaten mempengaruhi jawaban dan interaksi saat wawancara, sebagian kecil menandakan dengan pengetahuan menstruasi yang kurang dikarenakan tingkat ekonomi yang menengah ke bawah.

Terdapat perbedaan pada hasil penelitian dari Matta (2014) bahwa usia menarche remaja putri di SMPN 87 Jakarta Selatan lebih dari $>12$ tahun sebanyak 59,9\%. Hal ini didukung dengan pernyataan dari Maidartati et al (2016) bahwa usia pubertas remaja putri 11-15 tahun dengan usia temuda menstruasi di usia 10 atau 8 tahun.

\section{2) Otonomi Pribadi}

Maidartati, et al (2016) mengatakan dalam hasil penelitiannya bahwa remaja putri yang berusia 13-15 tahun sebagian besar memiliki pengetahuan yang cukup tentang kebersihan organ kewanitaan. Penelitian lain juga mengatakan bahwa ada hubungan antara pengetahuan tentang personal hygiene saat menstruasi dengan perilaku remaja saat menstruasi di SMP Islam Terpadu Harapan Bunda Pedurungan Semarang (Luthfiana, 2014).

Analisis dari tingkat pengetahuan yang ditemukan Tarigan (2012) sesuai dengan hasil penelitian di SMP PGRI 13 Kota Bogor 
pada tahun 2017, bahwa informan yang mengikuti PKPR tidak menjamin berperilaku baik, karena materi PKPR yang didapat informan materi pengetahuan kesehatan yang umum seperti DBD, lingkungan, dan narkoba. Namun ternyata hampir seluruh informan mendapatkan informasi dari Ibu mereka yang menjadikan sebagian besar informan yang tidak mengikuti PKPR memiliki perilaku yang baik dalam praktek hygiene menstruasi.

\section{3) Situasi Aksi}

Pada saat menstuasi tentunya banyak hal yang perlu diperhatikan, seperti mencuci organ dan penggantian pembalut. Penggantian pembalut yang benar adalah 4-5 kali dalam sehari selama menstruasi ketika mandi dan buang air, frekuensi yang kurang dalam mengganti pembalut akan menimbulkan iritasi dan berkembangnya jamur pada organ kewanitaan (Matta, 2014). Selain mengganti pembalut ternyata sebanyak $46 \%$ remaja putri yang mencuci organ kewanitaan dan memakai sabun saat mengganti pembalut (Suryati, 2012).

Situasi aksi mengenai kebersihan menstruasi ini pada kedua kelompok informan, terdapat bahwa kelompok yang memiliki tindakan dalam praktek mulai dari mengganti pembalut, mencuci organ hingga mengganti celana dalam saat menstruasi, dipengaruhi oleh kebiasaan yang dilihat oleh informan di rumah dan dipraktekan oleh Ibu dan Kakak mereka. Khususnya untuk sabun yang dipakai oleh informan, terdapat temuan bahwa sebagian besar remaja putri dalam penelitian ini menyukai sabun cair untuk membersihkan organ kewanitaan.

Namun terdapat 1 informan di kelompok yang mengikuti PKPR yang menggunakan sabun krim untuk mencuci organ kewanitaan. Dikarenakan walaupun terpengaruh oleh informasi pada pelatihan dan pembinaan PKPR di sekolah, faktor lain berpengaruh yaitu kondisi ekonomi dan pekerjaan orang tua yaitu sebagai buruh tani.

\section{4) Tingkat Keparahan}

Pada tingkat keparahan dan keluhan yang dialami remaja putri dalam Kabir, et al (2014) sebanyak 50\% remaja putri di Dhaka, Bangladesh mengalami masalah yang diakibatkan menstruasi, $8 \%$ diantaranya mengalami rasa gatal terbakar di area vagina. Di Indonesia sendiri hasil penelitian Fitriyah (2014) mengalami gatal-gatal "setiap hari" sebesar 6,8\%, lalu 54,2\% "tidak setiap hari", dan sebesar 39\% "tidak pernah mengalami gatal-gatal".

Tingkat keparahan yang dirasakan informan menunjukkan bahwa, tingkat keparahan yang dirasakan informan tergantung dari perilaku informan dalam menjaga kebersihan saat menstruasi dan dengan cara mengatasi keluhan tersebut.

Ada beberapa temuan dalam penelitian ini diantaranya, sesuai dengan hasil peneliatian Indah (2012) menunjukkan bahwa siswi sering mengalami Pruritis vulvae (gatal pada organ kemaluan) pada pertengahan menstruasi sebanyak 39,2\% sedangkan siswi yang selalu mengalami Pruritus vulvae setiap harinya selama menstruasi sebanyak $25,2 \%$.

\section{5) Sumber terhadap Informasi}

Di negara bagian timur Iran para remaja putri banyak mendapatkan informasi dari Ibu sebesar $24,5 \%, 9,3 \%$ tenaga kesehatan yang profesional, $8,7 \%$ saudara, $7,7 \%$ anggota keluarga lain, 3\% buku dan majalah 2,7\%, media massa $1 \%$. Lalu di Nigeria sebesar $55,2 \%$ remaja putri telah mendapatkan pengetahuan dan pelatihan terhadap menarche (menstruasi pertama) dan kebersihan saat menstruasi.

Dalam kelompok yang mengikuti PKPR terdapat 1 informan yang jarang mendapatkan informasi di rumahnya oleh 
karena itu informan ini tidak mengetahui sabun yang baik untuk mencuci organ, dan apa akibatnya jika tidak mengganti pembalut, 1 informan mendapatkan dari internet hanya sebatas ingin mencari informasi tambahan saja. Sedangkan kelompok yang tidak mengikuti PKPR hanya ada 3 informan yang pernah mendapatkan informasi seputar menstruasi di sekolah. Satu diantaranya mengungkapkan sebuah jawaban yang menurut informan ini adalah fakta dari temannya yang mengalami langsung, fakta jika sedang menstruasi tidak boleh keramas karena mengakibatkan pingsan.

\section{6) Dukungan Sosial}

Dari hasil penelitian diskusi kelompok yang dilakukan oleh McMahon et al, (2011) di Kenya faktor pribadi dan lingkungan mempengaruhi sikap dan tindakan remaja dalam manajemen hygiene menstruasi. Pada penelitian Lestariningsih (2015) tentang hal kepercayaan atau mitos terdapat kesamaan tidak ada hubungan antara praktek higiene menstruasi dengan kepercayaan

Analisis perilaku personal hygiene menstruasi remaja putri ini sebagian besar mendapatkan informasi dari ibu. Sebagian informan yang mendapatkan informasi atau dukungan sosial dari ibu mereka yang terbuka dan tidak malu-malu bertanya dan bercerita, sedangkan informan yang mendapatkan informasi dari kakak mereka rata-rata anak ke 2 dan ke 3 yang memiliki kakak perempuan. Dengan mitos yang mereka dapat dari ibu, kakak dan teman.

\section{Kesimpulan}

Gambaran perilaku personal hygiene menstruasi remaja putri yang mengikuti pelaithan dan pembinaan PKPR di SMP PGRI 13 Kota Bogor tahun 2017 ini Cukup
Baik, karena sebagian besar informan sudah memiliki pengetahuan dan praktek yang mendukung. Saran terhadap pihak sekolah agar lebih meningkatkan perilaku siswi menjadi lebih baik lagi diperlukan kerjasama lintas sector dengan Puskesmas Sindang Barang terkait program Pelatihan dan Pembinaan PKPR.

\section{Referensi}

[1] Abajobir, Amanuel Alemu and Assefa Seme. (2014). Reproductive health Knowledge and services utilization among rural adolescents in east Gojjam zone, Ethiopia: a community based cross-sectional study. Journal BMC Health Services Research. Pages: 14:138.

[2] Agampodi, Sunneth B et all. (2008). Adolescents perception of Reproductive Health Care Services in Sri Lanka. Journal BMC Health Service Research. Pages: 8:98.

[3] Andrews, Gilly. (2009). Buku Ajar Kesehatan Reproduksi Wanital Editor, Gilly Andrews; Alih Bahasa, Sari Kurnianingsih et all; Editor Edisi Bahasa Indonesia, Dwi Widiarti, Renata Komalasari. Jakarta, Indonesia: Penerbit Buku Kedokteran EGC.

[4] Anggraeni, Dewi Ayu. (2016). Faktor-faktor yang Berhubungan dengan Praktik Manajemen Higiene Menstruasi pada Siswi SMAN A dan B Jakarta Timur Tahun 2016. Skripsi, Universitas Indonesia. Depok. 2016.

[5] Arsani, Ni Luh Kadek Alit et all. (2013). Peranan Program PKPR (Pelayanan Kesehatan Peduli Remaja) terhadap Kesehatan Reproduksi Remaja di Kecamatan Buleleng, Bali. Jurnal Ilmu Sosial dan Humaniora. Vol. 2, No.1, April 2013.

[6] Attieh, Elie et all. (2016). Feminine Hygiene Practices among Female Patients and Nurses in Lebanon. Journal Reproductive Health. Pages 13:59. (www.springer.com) diakses pada 15 Maret 2017 pukul 09.20 wib.

[7] Badan Pusat Statistik (BPS). (2015). Jawa Barat Dalam Angka 2015. Indonesia.

[8] Chandra, Nur Fitria. (2012). Gambaran Perilaku Seksual Remaja di Sekolah Menengah Kejuruan (SMK) Swasta X di Kota Depok. Skripsi. Fakultas Kesehatan Masyarakat. Universitas Indonesia.

[9] Chandra-Mouli, Venkatraman et al. (2017). Mapping The Knowledge And Understanding Of Menarche, Menstrual Hygiene And Menstrual Health Among Adolescent Girls In Low-And Middle-Income Countries. Journal 
Reproductive Health. Pages 14:30. (www.springer.com) diakses pada 15 Maret 2017 pukul 09.20.

[10] Daili, Sjaiful Fahmi, et all. (2011). Infeksi Menular Seksual, Edisi Keempat (cetakan kedua). Jakarta, Indonesia; Badan Penerbit FKUI.

[11] Dwikarya, M. (2005). Menjaga Organ Intim, Penyakit dan Penanggulangannya. Jakarta: Kawan Pustaka.

[12] Fakhri, Moloud et all. (2012). Promoting Menstrual Health among Persian Adolescent Girls from Low Socioeconomic Backgrounds: a Quasi-Experimental Study. BMC Public Health. Pages 12:193.

[13] Fidyawati. (2012). Hubungan Pengetahuan Kesehatan Reproduksi dengan Perilaku Personal Hygiene Remaja Putri SMPN 1 Seyegan Sleman Yogyakarta. Universitas Muhammadiyah Yogyakarta. (http://digilib.fkik.umy.ac.id/files/disk1/13/yo ptumyfkpp-gdl-fidyawati-641-1naskahpi.pdf . diakses pada 4 Maret 2017, 11:20)

[14] Fitriyah, Imarotul. (2014). Gambaran Perilaku Higiene Menstruasi pada Remaja Putri di Sekolah Dasar Negeri di Wilayah Kerja Puskesmas Pisangan. UIN Syarif Hidayatullah, Jakarta.

[15] Harjon, Bactiar. (2009). Meyakinkan Validitas dan Reliabilitas Data melalui Triangulasi dalm Penelitian Kualitatif. Depok : Universitas Indonesia.

[16] Hartanto. (2013). Instrumen Penelitian. Jakarta : Universitas Airlangga.

[17] Hennegen, Julie et all. (2016)._Schoolgirls' Experience and Appraisal of Menstrual Absorbents in rural Uganda: a crosssectional evaluation of reusable sanitary pads. Journal Reproductive Health. Pages: 13:143.

[18] Indah, Fufut Tri Nur. (2012). Kejadian Pruritus Vulvae saat Menstruasi Pada Remaja Putri. Universitas Airlangga.

[19] Izzati, Wisnatul dan Reni Agustiani. (2014). Hubungan pengetahuan dengan Pelaksanaan Personal Hygiene Genitalia saat Menstruasi pada Remaja Putri Kelas IX SMP Negeri 4 Bukittinggi. STIKES Yarsi Bukittinggi,Sumatera Barat.

[20] Jaringan Pemberitaan Pemerintah. (Mei 30, 2017). Manajemen Kebersihan Menstruasi Harus diajarkan sejak Dini. Diakses pada: Agustus 14, 2017. https://jpp.go.id/humaniora/kesehatan/30678 1-manajemen-kebersihan menstruasiharus-diajarkan-sejak-dini

[21] Kabir, Humayun et all. (2014). Treatmentseeking for selected Reproductive health problems: behaviours of unmarried female adolescents in two low performing areas of Bangladesh. Journal Reproductive Health. Pages:11:54.

[22] Kementerian Kesehatan RI. (2015). Situasi Kesehatan Reproduksi Remaja. Pusat Data dan Informasi. Jakarta.

[23] Kesehatan Indonesia. Indonesia.

[24] Khasanah, Khotimatul et all. (2015). Hubungan pengetahuan tentang Menstruasi dengan Perilaku Personal Hygiene saat Menstruasi: Studi pada Siswi SMP 1 Bojong Kelas VII dan VIII, Kabupaten Pekalongan. STIKES Muhammadiyah Pekajangan Pekalongan.

[25] Krause, Sandra et all. (2015). Reproductive Health services for Syrian refugees in Zaatri Camp and Irbid City, Hashemite Kingdom of Jordan: an evaluation of the Minimum Initial Services Package. Journal Conflict and Health. (www.springer.com) diakses pada 15 Maret 2017 pukul 11.05 wib.

[26] Kusmiran, Eny. (2011). Kesehatan Reproduksi Remaja dan Wanita. Jakarta, Indonesia: Salemba Medika.

[27] Komalasari, Tresna. (2015). Faktor-faktor yang Berhubungan dengan Perilaku Personal Hygiene Siswa Kelas VII-Viii pada Saat Menarche di SMPN 2 Majalengka Tahun 2015. Jurnal Keperawatan dan Kesehatan AKPER YPIB. Majalengka. Volume II Nomor 3 Februari 2016.

[28] Lembaga Ilmu Pengetahuan Indonesia (LIPI). (2013). Konsep Pedoman Penilaian Etika Penilaian dan Publikasi. Jakata : Majelis Profesor Riset.

[29] Lestariningsih, Sri. (2015). Faktor-faktor yang Berhubungan dengan Praktek Higiene Menstruasi. jurnal Kesehatan Metro Sai Wawai Volume VIII No. 2 Edisi Desember 2015, ISSN: 19779-496X. Tanjungkarang.

[30] Lianawati, Iis. (2012). Tingkat pengetahuan Remaja Putri tentang Personal Hygiene saat Menstruasi pada Siswi Kelas X SMA Islam Terpadu Al Masyhur Pati. Surakarta.

[31] Luthfiana, Dewi Ana. (2014). Hubungan pengetahuan tentang Personal Hygiene dengan Perilaku Personal Hygiene Remaja saat Menstruasi di Sekolah Menengah Pertama Islam Terpadu Harapan Bunda Pedurungan Semarang. Skripsi. STIKES Ngudi Waluyo Ungaran. Semarang.

[32] Maidartati, et all. (2016). Hubungan pengetahuan dengan Perilaku Vulva Hygiene pada saat Menstruasi Remaja Putri. Jurnal Ilmu Keperawatan, Vol.IV, Halaman 50. 
[33] McMahon, Shannon A et all. (2011). 'The Girl with her Period is the one to hang Her head' Reflections on Menstrual Management among Schoolgirls in rural Kenya. BMC International Health and Human Right. Pages: 11:7.

[34] Matta, Marella dan Caroline Endah Wuryaningsih. (2014). Faktor-faktor yang Berhubungan dengan Perilaku Menstruasi pada Siswi SMPN 87 Jakarta Selatan Tahun 2014. Skripsi. Universitas Indonesia. Depok.

[35] Notoatmodjo, Soekidjo. (2011). Kesehatan Masyarakat: Ilmu dan Seni. Jakarta, Indonesia: PT. Rineka Cipta.

[36] Peraturan Menteri Kesehatan RI. Nomor 97 tahun 2014. Tentang Pelayanan Kesehatan Masa Sebelum Hamil, Masa Hamil, Persalinan, dan Masa Sesudah Melahirkan, Penyelenggaraan Pelayanan Kontrasepsi, serta Pelayanan Kesehatan Seksual. Indonesia.

[37] Pinarti, Astri Anggun. (2014). Perilaku menjaga Kebersihan Organ saluran Reproduksi pada Remaja Putri di SMP Kecamatan Tanjung Priok, Jakarta Utara. Universitas Indonesia. Depok.

[38] Nomor 25 tahun 2014. Tentang Upaya Kesehatan Anak. Indonesia.

[39] Nomor 61 tahun 2014. Tentang Kesehatan Reproduksi. Indonesia.

[40] Permatasari, Mareta Wulan et all. (2012). Hubungan Tingkat Pengetahuan Remaja Putri tentang Personal Hygiene dengan Tindakan Pencegahan Keputihan Di SMA Negeri 9 Semarang. Semarang.

[42] Provinsi Jawa Barat. (2012). Profil Kesehatan. Indonesia.

[43] Rahmayanti, Novita. (2012). Perilaku Keperawatan Kesehtaan Alat Reproduksi dalam Pencegahan Kanker Serviks pada Siswi SMAN 9 Kebon Kelapa Jakarta Timur. Skripsi. Universitas Indonesia. Depok.

[44] Sari, Ervina et all. (2012). Pengaruh Pendidikan Kesehatan tentang Hygiene saat Menstruasi terhadap Pengetahuan dan Keterampilan Remaja Putri dalam Merawat Perineum saat Menstruasi.

[45] Saydam, Dra. Syafni G. (2012). Waspadai Penyakit Reproduksi Anda!! Dan Berbagai Masalah Seks dari A-Z. Bandung, Indonesia: Pustaka Reka Cipta.

[46] Sommer, Marni et all. (2015). Putting Menarche and Girls into The Global Population Health Agenda. Journal Reproductiv Health. Pages 12:24.
[47] Survei Demografi dan Kesehatan Indonesia (SDKI). (2012).Kesehatan Reproduksi Remaja. Jakarta: Indonesia.

[48] Sugiyono. (2014). Metode Penelitian Kuantitatif Dan Kualitatif dan $R \& D$. Bandung, Indonesia: Alfabeta.

[49] Suryati. (2012). Perilaku kebersihan remaja saat menstruasi. Jurnal Health Quality, Vol. 3 No. 1, November 2012, halaman 54.

[50] Tarigan, Windurenny Jacinta. (2013). Gambaran tentang Hubungan Pengetahuan dan Sikap dengan Praktik Higiene Menstruasi pada Remaja Putri kelas 7 dan 8 di SMPN 141 Jakarta Selatan tahun 201. Skripsi, Universitas Indonesia. Depok. 2013.

[51] Tegegne, Teketo Kassaw et all. (2014). Menstrual Hygiene Management and school absenteeism among Female adolescent students in Northeast Ethiopia. BMC Public Health. Pages 14:1118.

[52] UNICEF Indonesia. 2015. Manajemen Kebersihan Menstruasi. diakses pada: Juli 23,

2017. http://unesdoc.unesco.org/images/0022/0022 67/226792e.pdf

[53] Widyastuti, Yani, et all. (2010). Kesehatan Reproduksi. Yogyakarta, Indonesia: Fitramaya.

[54] Wolff K, Johnson RA. Fitzpatrick's. (2009). Color atlas and synopsis of clinical dermatology. Edisi ke-6. New York:McGraw Hill; 73-86

[55] Yusiana, Maria Anita et all. (2016). Perilaku Personal Hygiene Remaja Putri pada saat Menstruasi. Jurnal STIKES Vol. 9 No. 1 Juli 2016, halaman 14.

[56] http://kependudukanjambi.org/dl/uu.no-10thn-1992-ttg-kependudukan-pemb-kelsejahtera.pdf - UU No 10 tahun 1992 tentang Pengembangan Kependudukan dan Keluarga Sejahtera

[57] http://www.kebijakanaidsindonesia.net/id/ber anda/42-kebijakan-kesehatan-healthpolicy/1222-kepmenkes-ri-nomor-1874tahun-2011-tentang-kelompok-kerjanasional-kesehatan-reproduksi - Permenkes No 433/Menkes/SK/1998 tentang Pembentukan Komisi Kesehatan Reproduksi 